\title{
Students' Worksheet for Distance Learning Based on Scientific Literacy in the Topic Coronavirus Disease 2019 (COVID-19)
}

\author{
Adib Rifqi Setiawan \\ Pondok Pesantren Ath-Thullab, Madrasah Tasywiquth Thullab Salafiyyah (TBS) \\ Jl. KH. Turaichan Adjhuri No.234, Langgardalem, Kota, Kudus, Indonesia \\ alobatnic@gmail.com \\ Surotul Ilmiyah \\ Xiangya School of Public Health, Central South University (CSU) \\ 932 Lushan S Rd, Yuelu District, Changsha, Hunan, China \\ surotul.ilmiyah@csu.edu.cn
}

\begin{abstract}
This research aims to design and implement primary student worksheets that can trace scientific literacy through distance learning in the topic Coronavirus disease 2019 (COVID19). The approach used is mixed method sequential exploratory model involving 35 primary students who take the distance learning due COVID-19 as a sample. The research instrument uses primary student worksheets designed based on the core stage of the scientific approach and scientific literacy's indicator, that have been reviewed and judged by experts. The implementation shows that the student's scientific literacy has not been trained optimally, alhtough this design could be responded to by students during learning.
\end{abstract}

Keywords : COVID-19; distance learning; scientific literacy; student worksheets; 


\section{Pendahuluan}

COVID-19 merupakan penyakit menular yang disebabkan oleh sindrom pernapasan akut coronavirus 2 (severe acute respiratory syndrome coronavirus 2 atau SARS-CoV-2) (Hui, et al., 2020; Ilmiyah, 2020). Virus ini merupakan keluarga besar Coronavirus yang dapat menyerang hewan, termasuk manusia. Ketika menyerang manusia, Coronavirus biasanya menyebabkan penyakit infeksi saluran pernafasan, seperti flu, MERS, dan SARS (Ilmiyah, 2020). COVID-19 sendiri merupakan coronavirus jenis baru yang ditemukan di daerah Wuhan, Hubei, China pada tahun 2019 (Hui, et al., 2020). Karena itu, Coronavirus jenis baru ini diberi nama Coronavirus disease-2019 yang disingkat menjadi COVID-19. Sejak ditemukan, virus ini menyebar secara luas hingga mengakibatkan pandemi global yang berlangsung sampai saat ini (Hui, et al., 2020). Gejala COVID-19 umumnya berupa demam $38^{\circ} \mathrm{C}$, batuk kering, dan sesak nafas serta dampak paling buruk untuk manusia ialah kematian (Hui, et al., 2020; Ilmiyah, 2020). Sampai 6 April 2020 pukul 22:00 WIB, dilaporkan terdapat 1.289.380 kasus terkonfirmasi dari 208 teritori yang 70.590 orang diantaranya meninggal dunia serta 270.372 orang bisa disembuhkan (Johns Hopkins CSSE, 2020).

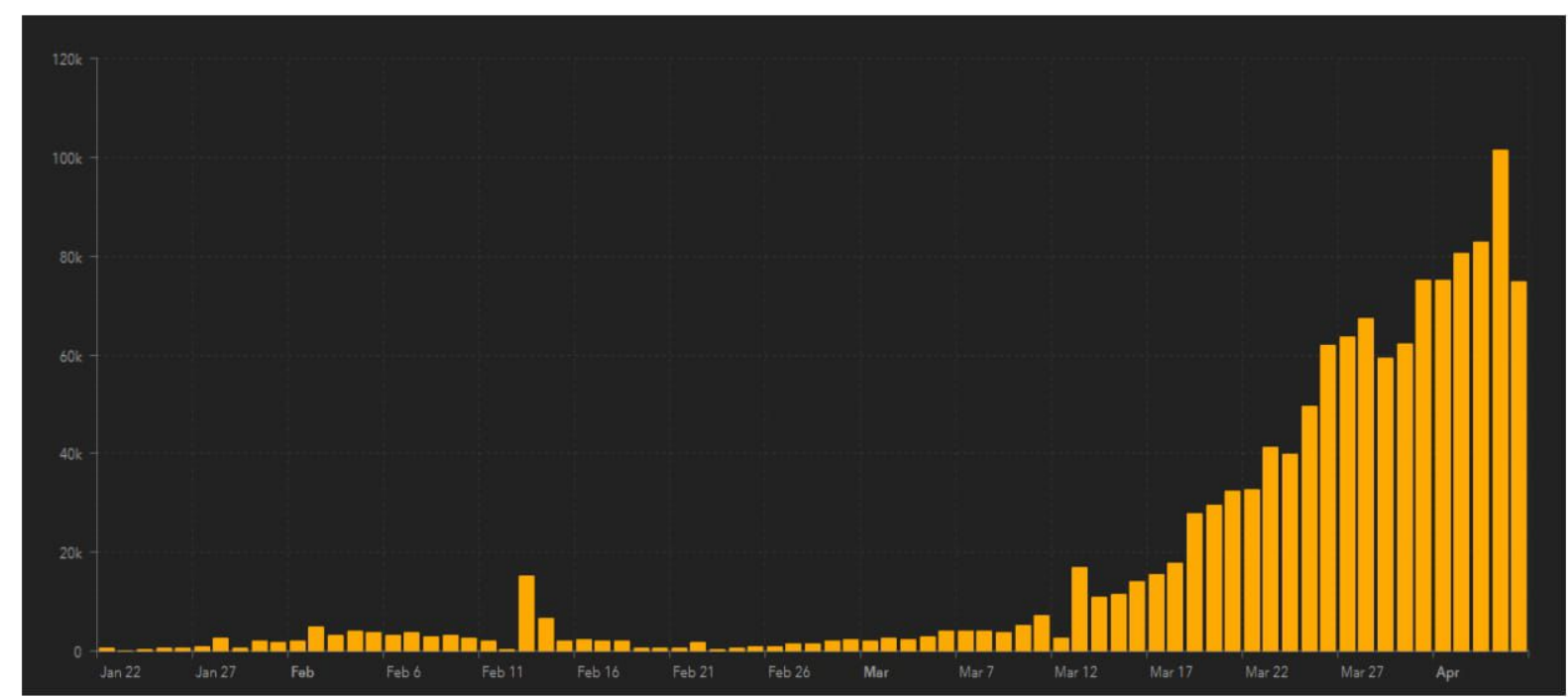

Gambar 1. Grafik harian pandemi global COVID-19 (Johns Hopkins CSSE, 2020)

Salah satu dampak pandemi Coronavirus 2019-20 ialah terhadap pendidikan di seluruh dunia, yang mengarah kepada penutupan luas sekolah, madrasah, universitas, dan pondok pesantren. Penulis pertama sebagai salah satu pengajar di madrasah dan pondok pesantren di Indonesia, turut merasakan dampak tersebut berupa perubahan pelaksanaan pembelajaran. Sementara penulis kedua yang sedang mengambil studi doktoral di China, sampai saat ini belum bisa kembali ke universitas. Hasil pantauan UNESCO menyebutkan bahwa lebih dari 188 negara telah menerapkan penutupan nasional yang berdampak kepada 1.576.021.818 siswa (91,3\% dari populasi siswa dunia) (UNESCO, 2020). Lebih lanjut, UNESCO pada 4 Maret 2020 menyarankan penggunaan pembelajaran jarak jauh dan membuka platform pendidikan yang dapat digunakan sekolah dan guru untuk menjangkau peserta didik dari jarak jauh dan membatasi gangguan pendidikan (UNESCO, 2020). Sehubungan dengan perkembangan tersebut, Kementerian Pendidikan dan Kebudayaan (Kemendikbud) turut mengambil kebijakan yang disampaikan melalui Surat Edaran Nomor 3 Tahun 2020 tentang Pencegahan COVID-19 sebagai panduan dalam menghadapi penyakit tersebut di tingkat satuan pendidikan (Kemendikbud, 2020). 
Keadaan tersebut membuat penulis pertama sebagai pengajar di madrasah turut menyusun lembar kegiatan siswa (LKS), guna memandu pembelajaran jarak jauh yang tidak banyak berbeda dengan kegiatan di sekolah. Sebagai pengajar, penulis pertama telah menerapkan pembelajaran literasi saintifik sejak awal tahun pembelajaran. Karena itu, diharapkan pembelajaran jarak jauh tetap mempertahanan proses pembelajaran literasi saintifik walau dengan cara dan tingkat berbeda. Sementara penulis kedua sebagai Sekretaris Satuan Tugas PBNU Cegah Covid-19 telah menyiapkan protokol di lembaga NU setiap tingkatan guna diberlakukan di klinik, lembaga pendidikan, dan masjid yang berafiliasi dengan NU. Protokol ini disiapkan sebagai upaya agar warga NU dan masyarakat secara luas dapat memahami tentang COVID-19, bisa mencegahnya agar tidak terinfeksi, serta tidak panik dalam menanggapi. Guna menyelaraskan upaya penulis pertama dan kedua, kami secara bersama menyusun LKS berdasarkan indikator literasi saintifik yang memuat topik COVID-19. Melalui riset ini, kami menyampaikan tentang susunan dan pelaksanaan LKS tersebut. Karena itu, pertanyaan yang menjadi fokus riset ini ialah, "Bagaimana lembar kegiatan siswa sekolah dasar untuk pembelajaran jarak jauh berdasarkan literasi saintifik pada topik penyakit Coronavirus 2019 (COVID-19)?

\section{Metode}

Riset ini membutuhkan data berupa kajian pustaka tentang karakteristik pembelajaran jarak jauh, indikator literasi saintifik, informasi terkait COVID-19, serta survei dan hasil penerapan rancangan LKS. Berdasarkan tujuan riset dan kebutuhan data, kami memilih memakai metode kombinasi (mixed method) (Sugiyono, 2018; Creswell, 2014; Fraenkel, Wallen, \& Hyun, 2012). Pendekatan ini dipilih karena kami ingin menyusun LKS berdasarkan kajian pustaka terkait karakteristik pembelajaran jarak jauh dan indikator literasi saintifik yang memuat topik COVID-19. Susunan tersebut kemudian dilihat keabsahan dan keandalannya berdasarkan survei kemudian diterapkan ke dalam pembelajaran, untuk diulas lebih lanjut dari sisi pelaksanaan. Karena urutan awal menggunakan metode kualitatif dan akhir memakai metode kuantitatif, model kombinasi yang digunakan berupa eksploratoris berurutan (sequential exploratory) (Sugiyono, 2018; Creswell, 2014; Fraenkel, Wallen, \& Hyun, 2012).

\section{Hasil dan Pembahasan}

Pembelajaran jarak jauh adalah pembelajaran ketika siswa dan pengajar mungkin tidak selalu hadir secara fisik secara bersamaan di sekolah. Pelaksanaan dapat sepenuhnya jarak jauh (hybrid) atau campuran jarak jauh dengan kelas (blended). Salah satu upaya pembelajaran jarak jauh paling awal muncul dalam iklan berjudul Caleb Philipps, Guru metode baru Short Hand yang diterbitkan melalui koran Boston Gazette pada tahun 1728 (Holmberg, 2005, hal. 13). Iklan tersebut diterbitkan sebagai upaya pengajar mencari siswa yang ingin belajar melalui pembelajaran yang dikirimkan. Pembelajaran jarak jauh pertama seperti dialami pada saat ini dilakukan oleh Isaac Pitman pada tahun 1840-an, yang mengajarkan sistem steno dengan mengirimkan beberapa teks yang ditranskripsi menjadi steno pada kartu pos dan menerima transkripsi dari para siswa dengan imbalan koreksi (Simonson, 2019, hal. 18). Unsur umpan balik siswa adalah inovasi penting dari sistem Isaac Pitman. Perkembangan penggunaan internet telah menjadikan pembelajaran jarak jauh lebih mudah dan cepat, bahkan saat ini sekolah virtual dan universitas virtual memberikan kurikulum daring penuh (Gold \& Maitland, 1999). Di Indonesia, salah satu universitas yang membuka fasilitas pembelajaran jarak jauh blended ialah program pasca sarjana Pendidikan IPA Universitas PGRI Semarang (UPGRIS) (Roshayanti, 2019). 
Beberapa kelebihan pembelajaran jarak jauh antara lain: dapat memperluas akses pendidikan untuk masyarakat umum dan bisnis karena struktur penjadwalan yang fleksibel mengurangi efek dari banyak kendala waktu dan tempat, penyerahan beberapa kegiatan di luar lokasi mengurangi kendala kapasitas kelembagaan yang timbul dari kebutuhan bangunan infrastruktur kelembagaan, serta terdapat potensi untuk meningkatkan akses ke lebih banyak pakar dari beragam latar belakang geografis, sosial, budaya, ekonomi, dan pengalaman. Namun, pembelajaran jarak jauh juga memiliki kekurangan antara lain: hambatan untuk pembelajaran efektif seperti gangguan rumah tangga dan teknologi yang tidak dapat diandalkan, interaksi yang tidak memadai antara siswa dan pengajar, serta kebutuhan untuk pengalaman yang lebih banyak.

Pengamatan naturalistic yang kami lakukan terhadap pelaksanaan pembelajaran jarak jauh di Kabupaten Kudus menunjukkan bahwa beberapa siswa lebih banyak berupaya untuk beradaptasi dengan platform daripada kegiatan pembelajaran serta kesulitan dalam manajemen waktu dan disiplin diri. Karena itu, kami melihat bahwa siswa dan pengajar perlu menyepakati platform yang digunakan sekaligus waktu pelaksanaan. Kesepakatan ini harus diambil untuk mengurangi potensi gagal hanya karena tidak bisa menggunakan platform sekaligus tetap terdapat interaksi langsung selama pembelajaran (Setiawan, 2020).

Sehubungan dengan keadaan tersebut, pembelajaran jarak jauh yang kami lakukan menggunakan platform WhatsApp. Layanan olah pesan ini dipilih karena biasa dipakai oleh pengajar (penulis pertama) sekaligus siswa (sampel) serta memungkinkan pengguna untuk mengirim pesan teks dan pesan suara, melakukan panggilan suara dan video, berbagi gambar, video, dokumen, lokasi pengguna, dan media lainnya. Waktu yang disepakati oleh pengajar dan siswa ialah pada pagi-siang hari seperti waktu sekolah pada umumnya. Kesepakatan waktu ini diambil agar proses pembelajaran tetap mempertahankan sisi interaksi secara langsung. Pelaksanaan dilakukan dengan memberi bahan panduan kegiatan yang dibagikan melalui grup WhatsApp guna dilaksanakan kemudian hasilnya dilaporkan secara pribadi. Kekurangan cara ini ialah tidak langsung dapat menanggapi pertanyaan dan/atau laporan pelajar, tapi memiliki kelebihan berupa lebih bersifat personal ketimbang klasikal.

Tabel 1. Indikator literasi saintifik setiap kompetensi

\begin{tabular}{|c|c|c|}
\hline Kompetensi & Indikator & Kode \\
\hline \multirow{2}{*}{$\begin{array}{l}\text { Menjelaskan masalah } \\
\text { secara ilmiah }\end{array}$} & Menerapkan pengetahuan ilmiah yang sesuai & A1 \\
\hline & Menyusun pertanyaan berdasarkan fokus masalah & A2 \\
\hline \multirow[b]{2}{*}{$\begin{array}{c}\text { Merencanakan } \\
\text { penyelidikan ilmiah }\end{array}$} & Menentukan variabel penyelidikan & B1 \\
\hline & $\begin{array}{l}\text { Mengusulkan cara mengeksplorasi secara ilmiah terhadap } \\
\text { pertanyaan yang diberikan }\end{array}$ & B2 \\
\hline \multirow{2}{*}{$\begin{array}{c}\text { Melakukan penyelidikan } \\
\text { ilmiah }\end{array}$} & $\begin{array}{l}\text { Mengidentifikasi, menggunakan, dan menghasilkan model dan } \\
\text { representasi yang jelas }\end{array}$ & B3 \\
\hline & Mengidentifikasi asumsi, bukti, dan penalaran dalam bacaan & B4 \\
\hline \multirow{2}{*}{$\begin{array}{c}\text { Menafsirkan data secara } \\
\text { ilmiah }\end{array}$} & $\begin{array}{c}\text { Menyajikan data menggunakan beragam representasi yang } \\
\text { sesuai }\end{array}$ & A3 \\
\hline & Menafsirkan data secara ilmiah & A4 \\
\hline \multirow{2}{*}{$\begin{array}{c}\text { Mengevaluasi } \\
\text { penyelidikan ilmiah }\end{array}$} & $\begin{array}{l}\text { Mengevaluasi cara mengeksplorasi secara ilmiah terhadap } \\
\text { pertanyaan yang diberikan }\end{array}$ & B5 \\
\hline & $\begin{array}{c}\text { Mengevaluasi argumen dan bukti ilmiah dari beragam tipe } \\
\text { sumber }\end{array}$ & B6 \\
\hline \multirow{2}{*}{$\begin{array}{l}\text { Mengomunikasikan } \\
\text { informasi ilmiah }\end{array}$} & Menyimpulkan informasi berdasarkan analisis & A5 \\
\hline & Menjelaskan manfaat pengetahuan ilmiah bagi masyarakat & A6 \\
\hline
\end{tabular}


Bahan panduan kegiatan tersebut berupa lembar kegiatan siswa (LKS) yang memuat langkah kegiatan serta saran referensi yang dapat digunakan. Saran referensi utama yang disampaikan ialah buku pelajaran yang dipakai ketika pembelajaran di sekolah. Sementara saran referensi tambahan berupa teks bacaan, gambar, audio, maupun video terkait topik yang dibahas. LKS disusun berdasarkan tahap inti pendekatan saintifik dan indikator literasi saintifik. Tahap tersebut berupa mengamati, menanya, mengolah informasi, mengomunikasikan hasil, serta menelaah kembali (Setiawan, 2017). Indikator literasi saintifik yang dipakai mengacu kepada Setiawan (2020), mencakup aspek menjelaskan masalah, menafsirkan data, dan mengomunikasikan informasi secara ilmiah serta merencanakan, melakukan, dan mengevaluasi penyelidikan ilmiah, yang secara rinci dapat dilihat melalui tabel 1 .

Tabel 2. Matriks indikator literasi saintifik dengan tahap inti pendekatan saintifik

\begin{tabular}{|c|c|c|c|}
\hline \multirow{2}{*}{ No. } & Pendekatan Saintifik & \multicolumn{2}{|l|}{ Literasi Saintifik } \\
\hline & Langkah & Kompetensi & Indikator \\
\hline 1 & \multirow{2}{*}{ Mengamati } & Menjelaskan masalah secara ilmiah & A1 \\
\hline 2 & & Melakukan penyelidikan ilmiah & B3 \\
\hline 3 & \multirow{3}{*}{ Menanya } & Merencanakan penyelidikan ilmiah & B1 \\
\hline 4 & & Menjelaskan masalah secara ilmiah & A2 \\
\hline 5 & & Merencanakan penyelidikan ilmiah & B2 \\
\hline 6 & \multirow{3}{*}{ Mengolah informasi } & Melakukan penyelidikan ilmiah & B4 \\
\hline 7 & & Menafsirkan data secara ilmiah & A3 \\
\hline 8 & & Menafsirkan data secara ilmiah & A4 \\
\hline 9 & \multirow{2}{*}{ Mengomunikasikan hasil } & Mengomunikasikan informasi ilmiah & A5 \\
\hline 10 & & Mengomunikasikan informasi ilmiah & A6 \\
\hline 11 & \multirow{2}{*}{ Menelaah kembali } & Mengevaluasi penyelidikan ilmiah & B5 \\
\hline 12 & & Mengevaluasi penyelidikan ilmiah & B6 \\
\hline
\end{tabular}

Topik yang dipakai untuk setiap LKS terkait dengan COVID-19. Kaitan tersebut dapat berupa penjelasan tentang COVID-19, dampak kebijakan terhadap lingkungan sosial, serta cara masyarakat menanggapi.

Tabel 3. Sebaran topik setiap LKS

\begin{tabular}{ccc}
\hline LKS & Topik & Pelajaran Terkait \\
\hline A & Teks Eksplanasi COVID-19 & Bahasa Indonesia \& IPA \\
\hline B & Upaya pencegahan COVID-19 & PPKn \& IPS \\
\hline C & Pembuatan Masker & IPA \& SBdP \\
\hline D & Gambar Peta Gejala COVID-19 di Tubuh Manusia & Bahasa Indonesia \& SBdP \\
\hline E & Kebijakan pencegahan COVID-19 & PPKn \& IPS \\
\hline F & Pembuatan Hand Sanitizer & IPA \& SBdP \\
\hline G & Pesan Para Dokter terkait Covid-19 & Bahasa Indonesia \& IPS \\
\hline H & Cara masyarakat menanggapi COVID-19 & PPKn \& IPS \\
\hline I & Pembuatan Disinfektan & IPA \& SBdP \\
\hline J & Tanggapan Grace Natalie terhadap COVID-19 & Bahasa Indonesia \& PPKn \\
\hline K & Keadaan Masyarakat Sekitar Ketika Pandemi COVID-19 & PPKn \& IPS \\
\hline L & Pembuatan Ember Berkran untuk Cuci Tangan & IPA \& SBdP \\
\hline
\end{tabular}


Keabsahan LKS ditentukan berdasarkan validasi pakar (Fraenkel, Wallen, \& Hyun, 2012). Validasi dilakukan terhadap keselarasan butir LKS dengan indikator literasi saintifik, kesesuaian butir LKS dengan langkah pembelajaran, ketepatan panduan penilaian dengan pertanyaan, serta kecocokan soal dengan jenjang sekolah. Pakar yang dipilih yaitu akademisi yang memiliki kepakaran literasi saintifik (1 orang) dan kesehatan (1 orang) serta praktisi pembelajaran sekolah dasar (1 orang) dan penyunting naskah bacaan anak (1 orang). Hasil validasi berupa penilaian terhadap setiap butir pertanyaan LKS yang diolah menggunakan persamaan 1 kemudian ditafsirkan berdasarkan tabel 4. Berdasarkan tabel tersebut, butir LKS dapat digunakan kalau memenuhi kriteria 'sangat layak' atau 'cukup layak'.

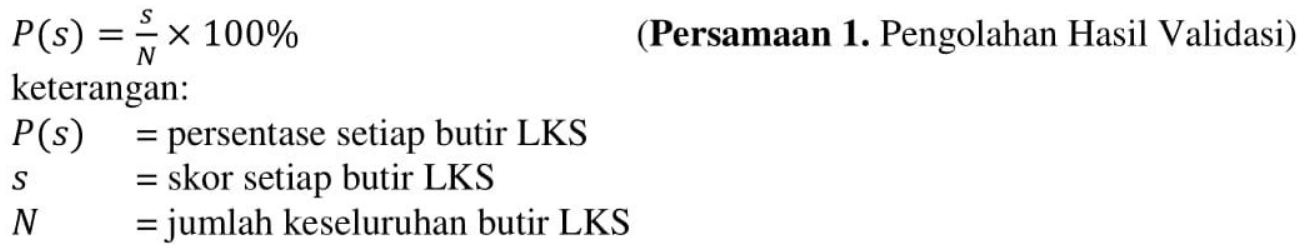

Tabel 4. Penafsiran Penilaian

\begin{tabular}{cc}
\hline Rentang Rerata Penilaian Pakar $(\%)$ & Kriteria Kelayakan Instrumen \\
\hline $7,001 \leq \% \leq 10,000$ & Sangat layak \\
\hline $4,001 \leq \% \leq 7,000$ & Cukup layak \\
\hline $0,000 \leq \% \leq 4,000$ & Tidak layak \\
\hline
\end{tabular}

Untuk keandalan LKS diukur berdasarkan nilai konsistensi internal yang diolah menggunakan persamaan 2. LKS memenuhi kriteria dapat digunakan kalau nilai $\propto$ sebagai acuan koefisien keandalan lebih besar dari 0,700 (Fraenkel, Wallen, \& Hyun, 2012; Cronbach, 1951).
$\alpha=\frac{n}{n-1}\left(1-\frac{\sum_{i} V_{i}}{V_{t}}\right)$
(Persamaan 2. Kuder-Richardson Approaches)
keterangan:
$\alpha \quad=$ koefisien alfa
$n \quad=$ jumlah butir LKS
$V_{i} \quad=$ simpangan baku setiap butir LKS
$V_{t} \quad=$ simpangan baku keseluruhan LKS

LKS tersebut diterapkan dalam pembelajaran jarak jauh kepada 35 siswa sekolah dasar yang mengalami pembelajaran jarak jauh seiring pandemi Coronavirus 2019-20. Karena itu, pengambilan sampel dalam riset ini menggunakan teknik convenience sampling (Fraenkel, Wallen, \& Hyun, 2012).

Tabel 5. Contoh matriks penyusunan butir LKS

\begin{tabular}{ccc}
\hline Pelajaran & $:$ & IPA \& SBdP \\
\hline Topik & $:$ & Pembuatan Hand Sanitizer \\
\hline Literasi Saintifik & $:$ & Mengevaluasi argumen dan bukti ilmiah dari beragam tipe sumber \\
\hline Langkah & $:$ & Menelaah kembali \\
\hline Pertanyaan & $:$ & Apa saja kelebihan dan kekurangan pembuatan hand sanitizer dalam video \\
& & tersebut? \\
\hline Panduan Penilaian & $:$ & $\begin{array}{c}\text { Siswa dapat menyebutkan kelebihan dan kekurangan dari sisi alat dan } \\
\text { bahan yang digunakan serta langkah pembuatan. }\end{array}$ \\
\hline Skor Maksimal & $:$ & 3 poin / butir pertanyaan \\
\hline
\end{tabular}


Hasil validasi pakar secara rinci dan keseluruhan pelaksanaan dapat dilihat melalui tabel 6 . Pelaksanaan yang dilakukan terbatas di satu kelas, yaitu kelas V di salah satu madrasah ibtidaiyyah di Kabupaten Kudus menunjukkan bahwa setiap LKS dapat ditanggapi oleh siswa selama pembelajaran jarak jauh. Rincian data menunjukkan bahwa tanggapan siswa (butir yang diisi) memiliki rerata 91,27 dan median 90,30 serta ketepatan tanggapan (butir yang tepat) memiliki rerata 76,43 dan median 75,69. Perbandingan antara tanggapan dan ketepatan setiap LKS ditampilkan melalui gambar 2, sementara ketepatan setiap butir dalam LKS berdasarkan semua indikator literasi saintifik ditunjukkan melalui tabel 7. Berdasarkan temuan yang ditunjukkan dapat dilihat bahwa literasi saintifik siswa belum dilatih secara optimal, walau setiap butir LKS dapat ditanggapi oleh siswa selama pembelajaran.

Tabel 6. Hasil validasi pakar dan pelaksanaan LKS

\begin{tabular}{ccccccccc}
\hline \multirow{2}{*}{ LKS } & \multicolumn{7}{c}{ Validasi Pakar } & \multicolumn{2}{c}{ Pelaksanaan } \\
\cline { 2 - 9 } & $\mathbf{1}$ & $\mathbf{2}$ & $\mathbf{3}$ & $\mathbf{4}$ & Rerata & Kelayakan & $\boldsymbol{\alpha}$ & Keandalan \\
\hline A & 7 & 6 & 7 & 7 & 6.75 & Cukup layak & 0,710 & Dapat digunakan \\
\hline B & 8 & 7 & 8 & 8 & 7.75 & Sangat layak & 0,798 & Dapat digunakan \\
\hline C & 8 & 7 & 6 & 7 & 7.00 & Cukup layak & 0,724 & Dapat digunakan \\
\hline D & 7 & 8 & 7 & 8 & 7.50 & Sangat layak & 0,732 & Dapat digunakan \\
\hline E & 8 & 6 & 5 & 7 & 6.50 & Cukup layak & 0,843 & Dapat digunakan \\
\hline F & 7 & 7 & 6 & 8 & 7.00 & Cukup layak & 0,701 & Dapat digunakan \\
\hline G & 8 & 7 & 8 & 7 & 7.50 & Sangat layak & 0,839 & Dapat digunakan \\
\hline H & 7 & 6 & 6 & 7 & 6.50 & Cukup layak & 0,703 & Dapat digunakan \\
\hline I & 8 & 7 & 6 & 8 & 7.25 & Sangat layak & 0,734 & Dapat digunakan \\
\hline J & 7 & 7 & 7 & 7 & 7.00 & Cukup layak & 0,839 & Dapat digunakan \\
\hline K & 7 & 8 & 6 & 7 & 7.00 & Cukup layak & 0,772 & Dapat digunakan \\
\hline L & 8 & 7 & 8 & 8 & 7.75 & Sangat layak & 0,824 & Dapat digunakan \\
\hline
\end{tabular}

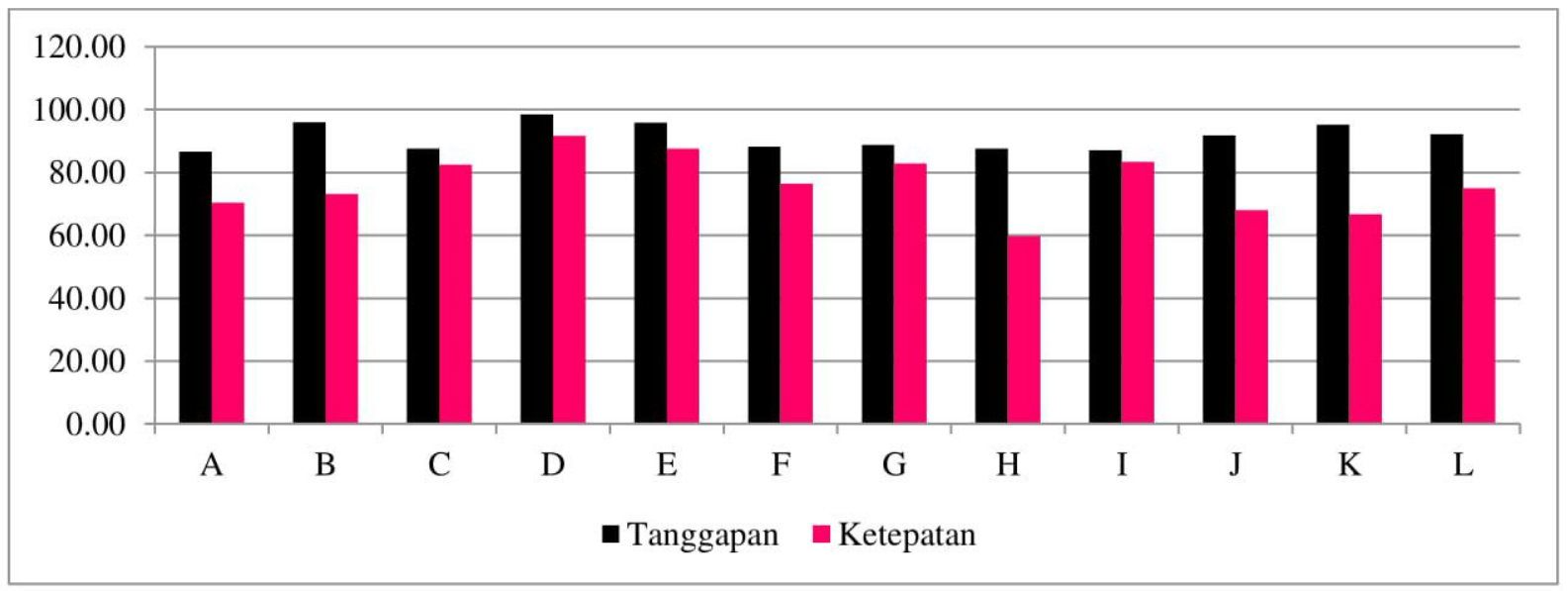

Gambar 2. Pelaksanaan setiap LKS

Profil literasi saintifik terendah didapat dari LKS H (Cara masyarakat menanggapi COVID19) untuk indikator A5 (menyimpulkan informasi berdasarkan analisis). Ketika pembelajaran, siswa diminta untuk menyimpulkan apakah Kabupaten Kudus sudah masuk zona merah atau belum berdasarkan informasi saduran berita PDP Virus Corona di Kudus Bertambah Lagi Jadi 22 Orang yang ditayangkan oleh Kompas.com pada 26 Maret 2020 pukul 19.12 WIB (Nugroho, 2020). Namun, ternyata siswa banyak yang belum bisa menyimpulkan secara tepat. Kelemahan pengetahuan istilah terkait mungkin turut memengaruhi hasil ini, misalnya pembedaan PDP (Pasien Dalam Pengawasan), ODP (Orang Dalam Pengawasan), dan OTG 
(Orang Tanpa Gejala). Karena itu, perlu dilakukan langkah awal berupa memastikan siswa sudah mengerti istilah terkait topik pembelajaran. Indikator A5 juga memiliki profil rendah dari LKS A (Teks Eksplanasi COVID-19). Berdasarkan teks eksplanasi yang disajikan, siswa masih kesulitan untuk menyimpulkan bagian tubuh yang secara umum menjadi sasaran serangan COVID-19. Kesalahan yang kami lakukan barangkali untuk LKS A yang dilakukan pertama ialah tidak menyertakan gambar rinci. Ini tampak dari butir LKS D (Gambar Peta Gejala COVID-19 di Tubuh Manusia) indikator B3 (mengidentifikasi, menggunakan, dan menghasilkan model dan representasi yang jelas) yang notabene menunjukkan titik tubuh yang diserang COVID-19 menghasilkan profil jauh lebih baik.

Tabel 7. Ketepatan setiap butir dalam LKS berdasarkan semua indikator literasi saintifik

\begin{tabular}{|c|c|c|c|c|c|c|c|c|c|c|c|c|}
\hline \multirow{2}{*}{ LKS } & \multicolumn{12}{|c|}{ Indikator } \\
\hline & A1 & A2 & A3 & A4 & A5 & A6 & B1 & B2 & B3 & B4 & B5 & B6 \\
\hline $\mathbf{A}$ & 63 & 50 & 38 & 38 & 33 & 42 & 46 & 58 & 71 & 71 & 67 & 58 \\
\hline B & 75 & 63 & 50 & 50 & 38 & 38 & 38 & 50 & 63 & 58 & 71 & 67 \\
\hline $\mathbf{C}$ & 67 & 63 & 63 & 58 & 54 & 58 & 58 & 63 & 63 & 63 & 67 & 67 \\
\hline D & 75 & 71 & 67 & 67 & 63 & 63 & 63 & 67 & 71 & 71 & 75 & 75 \\
\hline $\mathbf{E}$ & 71 & 67 & 63 & 63 & 58 & 63 & 63 & 67 & 71 & 67 & 71 & 67 \\
\hline $\mathbf{F}$ & 67 & 58 & 54 & 50 & 50 & 50 & 54 & 58 & 63 & 63 & 63 & 58 \\
\hline $\mathbf{G}$ & 67 & 63 & 58 & 58 & 50 & 54 & 58 & 63 & 67 & 67 & 75 & 67 \\
\hline $\mathbf{H}$ & 63 & 63 & 50 & 38 & 29 & 38 & 38 & 33 & 42 & 46 & 50 & 50 \\
\hline I & 71 & 67 & 67 & 58 & 54 & 54 & 58 & 58 & 58 & 67 & 71 & 67 \\
\hline $\mathbf{J}$ & 63 & 54 & 42 & 33 & 33 & 38 & 46 & 50 & 58 & 67 & 67 & 63 \\
\hline $\mathbf{K}$ & 50 & 44 & 38 & 38 & 38 & 44 & 44 & 50 & 56 & 63 & 69 & 69 \\
\hline $\mathbf{L}$ & 58 & 50 & 50 & 42 & 38 & 42 & 54 & 63 & 63 & 71 & 75 & 71 \\
\hline Me. & 65.63 & 59.20 & 53.13 & 49.31 & 44.79 & 48.44 & 51.56 & 56.60 & 61.98 & 64.24 & 68.23 & 64.76 \\
\hline Med. & 66.67 & 62.50 & 52.08 & 50.00 & 43.75 & 46.88 & 54.17 & 58.33 & 62.50 & 66.67 & 69.79 & 66.67 \\
\hline
\end{tabular}

Temuan tersebut menyampaikan bahwa LKS yang disusun perlu mengalami evaluasi sebelum dapat dipakai lebih luas. Pemakaian lebih luas dapat digunakan untuk keperluan praktik pembelajaran maupun replikasi riset. Dalam riset sosial, hasil yang diperoleh tidak memberi garansi bahwa keabsahan dan keandalan yang sama dapat berlaku untuk partisipan lain. Alasannya antara lain karena ruang lingkup pembahasan berada dalam spektrum tertentu. Kalau hanya mengambil simpulan akhir tanpa memperhatikan rincian tertentu seperti metode dan fokus pembahasan, berarti yang terjadi adalah implantasi atau pencangkokan. Karena itu, kami berharap supaya riset ini tidak dianggap final.

\section{Simpulan}

Riset ini memberi hasil berupa LKS untuk sekolah dasar yang dapat melacak literasi ilmiah melalui pembelajaran jarak jauh dalam topik penyakit Coronavirus 2019 (COVID-19). Lembar kegiatan siswa sekolah dasar dirancang berdasarkan tahap inti pendekatan saintifik serta indikator literasi saintifik. Hasil validasi pakar menunjukkan bahwa LKS layak digunakan. Ketika digunakan dalam pembelajaran, pelaksanaan menunjukkan bahwa literasi saintifik siswa belum dilatih secara optimal, walau susunan ini dapat ditanggapi oleh siswa selama pembelajaran. 


\section{Referensi}

Creswell, J. W. (2014). Research Design Qualitative, Quantitative, and Mixed Methods Approaches (Edisi Keempat ed.). (V. Knight, Penyunt.) Thousand Oaks: SAGE Publications.

Cronbach, L. J. (1951, Februari 28). Coefficient Alpha and the Internal Structure of Tests. Psychometrika, 16, 297-334.

Fraenkel, J. R., Wallen, N. E., \& Hyun, H. H. (2012). How to Design and Evaluate Research in Education (Edisi Kedelapan ed.). (S. Kiefer, Penyunt.) New York City: McGraw-Hill Companies.

Gold, L., \& Maitland, C. (1999). What's the difference? A review of contemporary research on the effectiveness of distance learning in higher education. Washington: Institute for Higher Education Policy.

Holmberg, B. (2005). The Evolution, Principles and Practices of Distance Education. Oldenburg : Bibliotheks-und Informationssystem der. Carl von Ossietzky Universität Oldenburg.

Hui, D. S., E., I. A., Madani, T. A., Ntoumi, F., Kock, R., Dar, O., et al. (2020, Februari). The continuing 2019-nCoV epidemic threat of novel coronaviruses to global health-The latest 2019 novel coronavirus outbreak in Wuhan, China. International Journal of Infectious Diseases, 91, 264-66.

Ilmiyah, S. (2020, Februari 11). Surotul Ilmiyah - PBNU Menjawab Tantangan Virus Corona. Dipetik April 6, 2020, dari https://www.youtube.com/alobatnic: https://youtu.be/SPdc4WT8BCg

Johns Hopkins CSSE. (2020, April 6). Coronavirus COVID-19 Global Cases by the Center for Systems Science and Engineering (CSSE) at Johns Hopkins University (JHU). Dipetik April 6, 2020, dari ArcGIS:

https://gisanddata.maps.arcgis.com/apps/opsdashboard/index.html\#/bda7594740fd402994234 $67 \mathrm{~b} 48 \mathrm{e} 9 \mathrm{ecf6}$

Kemendikbud. (2020, Maret 16). Surat Edaran Nomor 3 Tahun 2020 tentang Pencegahan COVID-19 pada Satuan Pendidikan. Dipetik April 6, 2020, dari LLDIKTI Wilayah I Sumatera Utara: https://ldiktil.ristekdikti.go.id/berkas/semendikbud032020pencegahancorona.pdf

Nugroho, P. D. (2020, Maret 26). PDP Virus Corona di Kudus Bertambah Lagi Jadi 22 Orang. Dipetik Maret 27, 2020, dari Kompas.com: https://regional.kompas.com/read/2020/03/26/19125571/pdp-virus-corona-di-kudusbertambah-lagi-jadi-22-orang?page=all\#page3

Roshayanti, F. (2019, Agustus 21). Desain Pembelajaran Sekolah Dasar. (A. R. Setiawan, Pewawancara)

Setiawan, A. R. (2017). Penerapan Pendekatan Saintifik untuk Melatihkan Literasi Saintifik dalam Domain Kompetensi pada Topik Gerak Lurus di Sekolah Menengah Pertama. Bandung: Universitas Indonesia.

Setiawan, A. R. (2020, April 6). Di Mana Letak Penting Lembaga Pendidikan? Dipetik April 6, 2020, dari Alobatnic: https://alobatnic.blogspot.com/2020/04/di-mana-letak-penting-lembagapendidikan.html

Setiawan, A. R. (2020, Januari 24). Pembelajaran Tematik Berorientasi Literasi Saintifik. Jurnal Basicedu: Journal of Elementary Education, 4(1), 71-80.

Simonson, M. (2019). Distance Learning Journal (Book 2) (Vol. 16). Charlotte: Information Age Publishing.

Sugiyono. (2018). Metode Penelitian Bisnis: Pendekatan Kuantitatif, Kualitatif, Kombinasi, dan R\&D (Edisi ke-3 ed.). (S. Y. Suryandari, Penyunt.) Bandung: Alfabeta.

UNESCO. (2020, Maret 4). 290 million students out of school due to COVID-19: UNESCO releases first global numbers and mobilizes response. Dipetik April 6, 2020, dari UNESCO: https://en.unesco.org/news/290-million-students-out-school-due-covid-19-unesco-releasesfirst-global-numbers-and-mobilizes

UNESCO. (2020, April 6). COVID-19 Educational Disruption and Response. Dipetik April 6, 2020, dari UNESCO: https://en.unesco.org/themes/education-emergencies/coronavirus-schoolclosures 